\title{
The credit crunch: impacts on the housing market and policy responses in the Netherlands
}

\author{
Hugo Priemus
}

Received: 6 November 2009/Accepted: 10 November 2009/Published online: 26 November 2009

(C) The Author(s) 2009. This article is published with open access at Springerlink.com

\begin{abstract}
This contribution deals with the impact of the credit crunch on the Dutch housing market and the policy responses of the Dutch government so far. Reinhart and Rogoff have presented an overview of credit crises after WW II: what are the general characteristics and impacts? Also in the Netherlands, banking problems were imported from the US. The open economy of the Netherlands appeared to be very vulnerable to the worldwide credit crunch. Also in this country the real economy worsened. Housing construction fell sharply, while prices of residential properties fell more gradually. After giving an overview of the Dutch government's current policies to stimulate housing construction and renovation, we consider whether the Dutch economy is following the general pattern sketched by Reinhart and Rogoff. If so, we could expect a continuation of the crisis on the housing and construction market for another 4 years.
\end{abstract}

Keywords Credit crisis · Housing market - Secondary mortgage market · Housing construction $\cdot$ House price $\cdot$ The Netherlands

\section{Introduction}

Countries all over the world are feeling the effects of the credit crunch. In this article we discuss the impact of the credit crunch on the Dutch housing market and the policy responses of the Dutch government so far. We start with a summary of the general findings of studies by Reinhart and Rogoff (2008a, b, 2009) and the International Monetary Fund (IMF) (2009a) on financial crises in advanced economies and countries in transition.

This is followed by an analysis of the developments on the Dutch housing market, importing problems from the USA mortgage market. At present-mid-2009— the Dutch construction industry is in disarray and the price of housing in the Netherlands does not

H. Priemus $(\bowtie)$

OTB Research Institute for Housing, Urban and Mobility Studies, Delft University of Technology, Jaffalaan 9, 2628 BX Delft, The Netherlands

e-mail: h.priemus@tudelft.nl 
seem to have suffered all that much. Then we give an overview of current policies of Dutch government to reduce the problems on the housing and construction markets.

If the Netherlands is destined to follow the pattern sketched by Reinhart and Rogoff (2009) and IMF (2009a), the crisis on the housing and construction market still has some way to go, even if the national economy were to make a speedy recovery.

\section{Aftermath of financial crises: general findings}

Reinhart and Rogoff (2008a, b, 2009) have carried out detailed analyses of systemic banking crises and identified around twenty serious crises since the end of WW II. They closely analysed the antecedents and aftermath of financial crises in advanced economies (USA 1929, Spain 1977, Norway 1987, Sweden 1991, Finland 1991 and Japan 1992) and countries in transition (Malaysia 1997, Indonesia 1997, Thailand 1997, the Philippines 1997, Hong Kong 1997, Korea 1997, Colombia 1998 and Argentina 2001). In both mature and emerging markets, they found broadly similar patterns in house and equity prices, unemployment, and government revenue and debt (see also: Janssen 2009; van Ewijk and Teulings 2009). The study of the aftermath of severe financial crises focused on 19 postwar cases and two pre-war cases.

Reinhart and Rogoff (2009) concluded that the aftermath of severe financial crises is usually characterised by three developments:

"First, asset market collapses are deep and prolonged. Real housing price declines average $35 \%$ stretched out over 6 years, while equity price collapses average $55 \%$ over a downturn of about three and a half years. Second, the aftermath of banking crises is associated with profound declines in output and employment. The unemployment rate rises an average of $7 \%$ points over the down phase of the cycle, which lasts on average over 4 years. Output (measured in Gross Domestic Product) falls (from peak to trough) an average of over $9 \%$, although the duration of the downturn, averaging roughly 2 years, is considerably shorter than for unemployment. Third, the real value of government debt tends to explode, rising an average of $86 \%$ in the major post-World War II episodes. Interestingly, the main cause of debt explosions is not the widely cited costs of bailing out and recapitalizing the banking system" (...) "In fact, the big drivers of debt increases are the inevitable collapse in tax revenues that governments suffer in the wake of deep and prolonged output contractions, as well as often ambitious countercyclical fiscal policies aimed at mitigating the downturn".

IMF (2009a: 125) gives an overview of economic indicators around peaks of current and previous recessions (Fig. 1), which illustrates the findings of Reinhart and Rogoff (2009).

Figure 2 shows the decline in real house prices and the duration of the downturn in two pre-war and 19 post-war crises, sorted out by Reinhart and Rogoff (2009).

Some of the countries in Fig. 2 (Austria, Hungary, Iceland, Ireland, Spain, the United Kingdom and the USA) are still in the throes of a banking crisis. Ongoing crises are in dark shading and past crises are in light shading. The historical average (coloured black in the diagram) does not include the ongoing crises.

Reinhart and Rogoff (2009) found that the cumulative decline in real housing prices from peak to trough averages $35.5 \%$. The most severe real housing price declines were experienced by Finland, the Philippines, Colombia and Hong Kong. Their crashes were $50-60 \%$, measured from peak to trough. The housing price decline experienced by the United States to date during the current episode (almost 28\% according to the Case-Shiller index) is already more than twice that registered in the US during the Great Depression. 


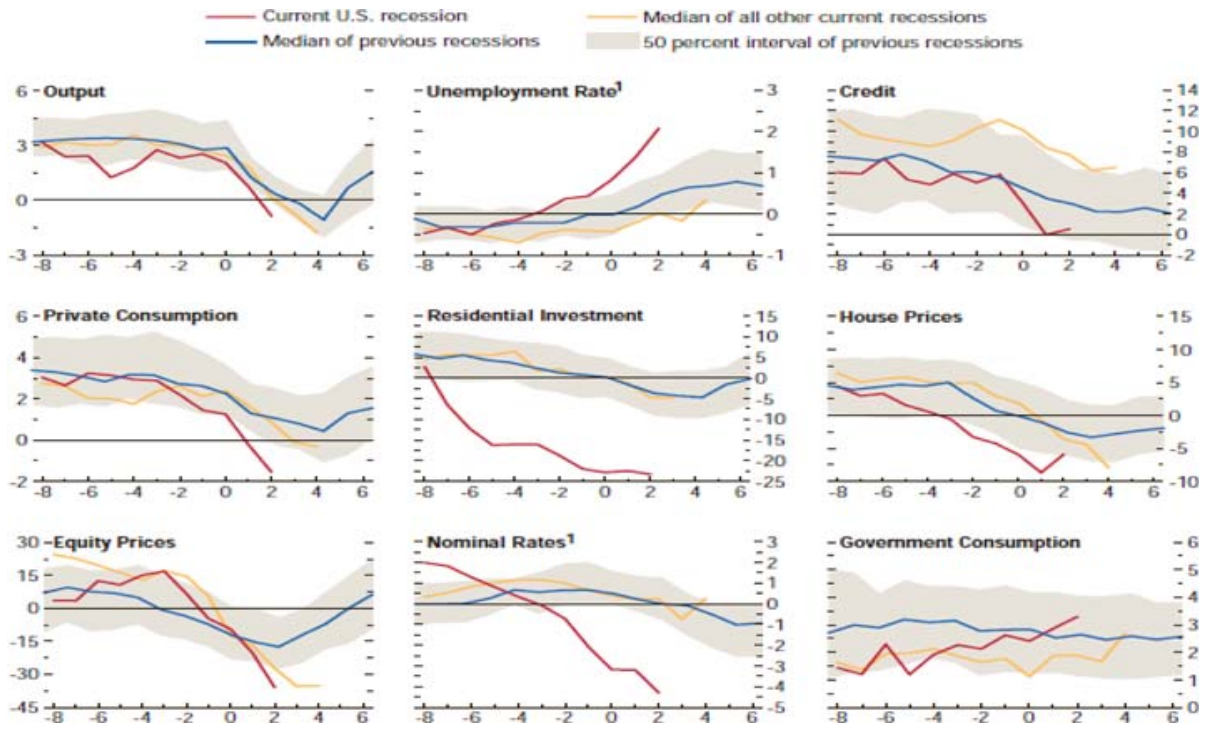

Fig. 1 Economic indicators around peaks of current and previous recessions (Median log differences from 1 year earlier unless otherwise noted; peak in output at $t=0$; data in real terms unless otherwise noted; quarters on the $x$-axis). 1 Median percentage point difference from 1 year earlier. Source: IMF (2009a: 125)

Notably, the duration of housing price declines is quite long-lived, averaging roughly 6 years. Even excluding the extraordinary experience of Japan (with its 17 consecutive years of price declines since 1992), the average remains over 5 years. Reinhart and Rogoff (2009) observe that falls in the stock market are sharper and shorter-lived than falls in the house prices.

Reinhart and Rogoff (2009) describe the mounting national debt as a defining characteristic of the aftermath of banking crises. They conclude that, so far, the current crisis in the US has followed the pattern of history. The historical facts paint a "sobering picture" of the way the current economic crisis will unfold in the coming years. Apparently, it still has a long way to go.

The IMF (2009a) confirms the findings of Reinhart and Rogoff and concludes that banking problems have a deeper impact on general economic crises than other causes and, in addition, that economic crises are most severe when they are highly synchronized, i.e. when they take place in many countries simultaneously (IMF 2009a: 113-114). The current economic crisis follows both definitions and, as a matter of fact, belongs to the most severe category identified by IMF (2009a) (Figs. 3 and 4).

The analysis by Reinhart and Rogoff (2008a, b, 2009) and the study of IMF (2009a, b) can serve as a template for interpreting the impact of the banking crisis on the Dutch housing market.

\section{Dutch banking problems: imported from the US}

Since the turn of the century, economic developments in the United States have been paralleled by a deterioration in the rate of the dollar against the euro. After the introduction 

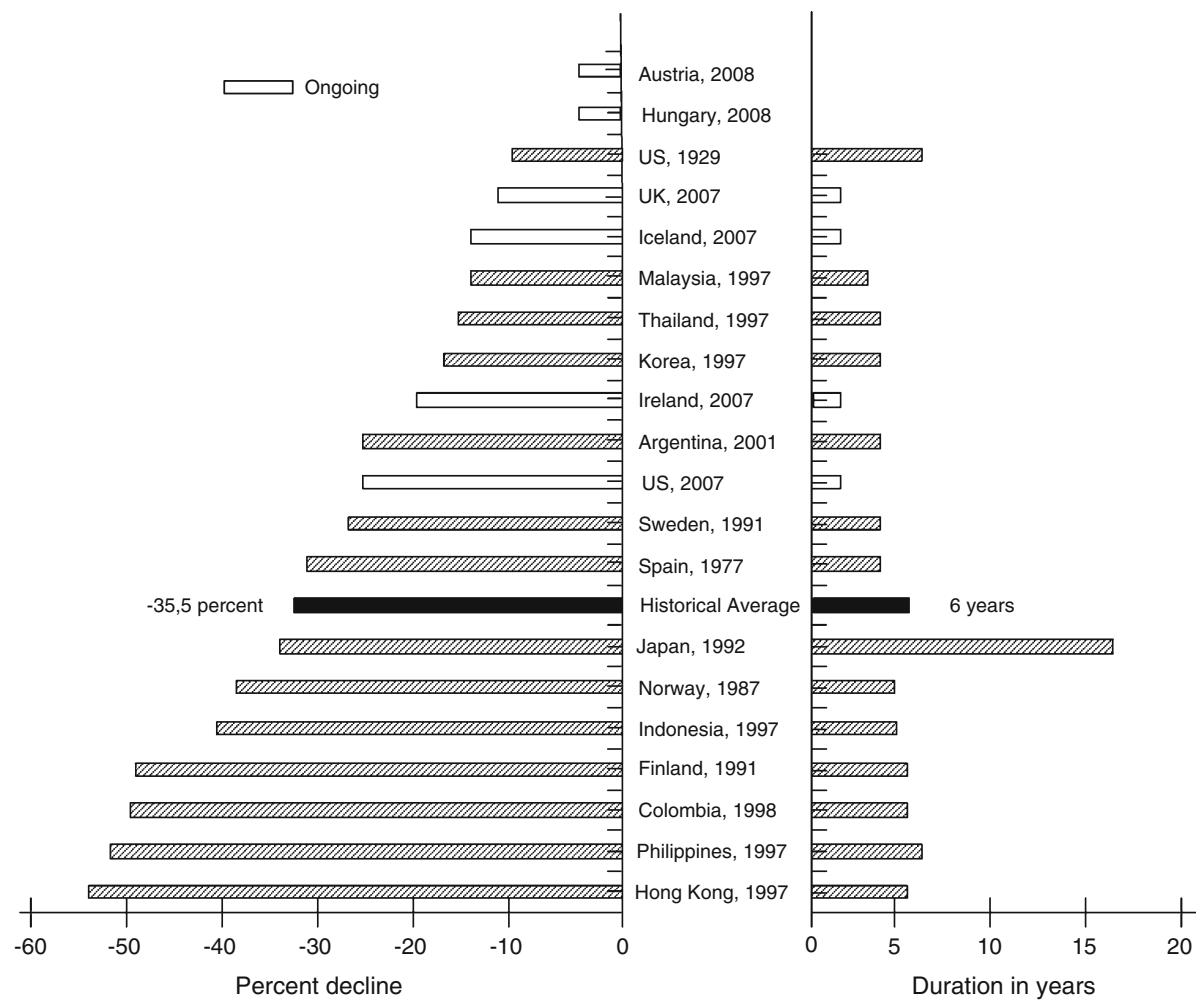

Fig. 2 Past and ongoing real house price cycles and banking crises: Peak-to-trough price declines (left panel) and years duration of downturn (right panel). Notes: Each banking crisis episode is identified by country and the beginning year of the crisis. Only major (systemic) banking crises episodes are included, subject to data limitations. The historical average reported does not include ongoing crises episodes. Consumer indices are used to deflate nominal house prises. Source: Reinhart and Rogoff (2009)

on 1 January 1999, the euro gradually lost value until it hit an all-time low with a decline of $30 \%$ on 26 October 2000 . Then it took a turn for the better and began its march to victory (de Groot 2008). Between January 2007 and March 2009 the volatility in the exchange rate of the US dollar against the euro was very high, as Fig. 5 illustrates (Centraal Planbureau (CPB) 2009: 43).

The credit crunch started in mid-2007 with major problems on the US mortgage market, particularly the subprime market (Di Martino and Duca 2007; Shiller 2008). Borrowers who use subprime lending have to pay interest rates which are 400 basis points higher than rates in the prime market (Pennington-Cross 2002: 31). The Federal Administration wanted to promote home-ownership among low-income households who could not meet the criteria of mortgage giants Fannie Mae and Freddie Mac.

The mortgage norms in America are lower than in the Netherlands. It is, for example, easier to get a loan in America, and interim re-mortgaging is available if the interest payments start to bite. Rises in the value of dwellings are often anticipated. In order to temporarily ease the burden, the interest is usually set for short periods (Buckley et al. 2003). Lower entry rates are offset later by an extra supplement. Interest-only mortgages with variable interest rates are very popular. Two-part mortgages are even available in 


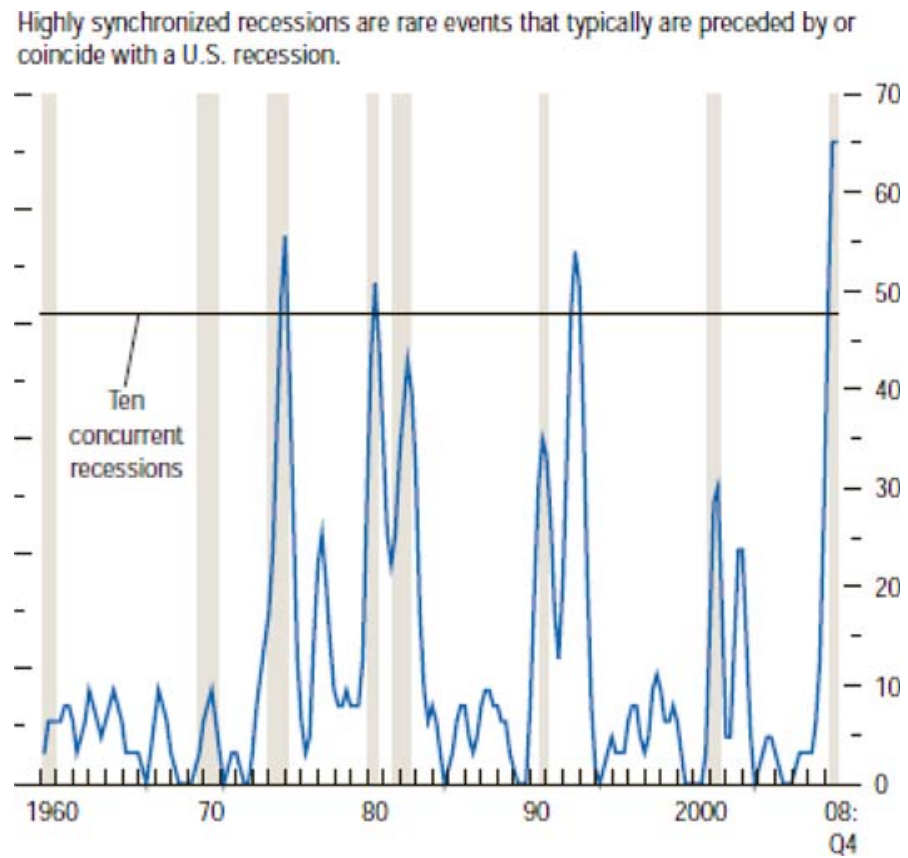

Fig. 3 Highly synchronized recessions (per cent of countries in recession; shaded areas denote US recession). Source: IMF (2009a: 113)

which the first part meets the requirements of the federal mortgage guarantee, while the second takes the form of a subordinated loan to finance the rest. Many Americans with a low credit rating have taken on a high mortgage in recent years.

The Clinton Administration relaxed the mortgage conditions for low-income households and inadvertently increased the popularity of Alt-A and subprime mortgages with a relatively high, variable interest rate and high risks for low-income households. The share of subprime mortgages in all mortgage loans rose from one tenth to one quarter.

The growth of subprime mortgages was a key trigger in the sudden demand for homes in less popular urban neighbourhoods (Wyly et al. 2006) - a trend which initially caused property prices to rocket. The outlook seemed good as long as house prices were on the increase, as long as the general economy was booming, and as long as jobs were relatively easy to find. But when the economy fell into stagnation and house prices began to fall in 2006, the problems came thick and fast. More and more households ran into payment difficulties and there was a sharp rise in the number of foreclosures (Sanders 2008).

Within 2 years, the US Federal Bank raised the interest rate from 1 to 5.25\%, thereby seriously compounding the affordability problems. By 2007, no fewer than three million compulsory sales were taking place on an annual basis.

Recent American research (Immergluck 2009; Schwartz 2008) suggests that this segment of the market is rife with fraud. Property is being sold at an alarming rate (flip-flop real estate) and price rises of between $25 \%$ and over $50 \%$ have been observed, particularly in low-income neighbourhoods, where compulsory sales are not uncommon. The services of 'front men' are used for this purpose, allowing those who orchestrate events to remain in the background and avoid detection. Often, these rapid increases begin in real estate that 

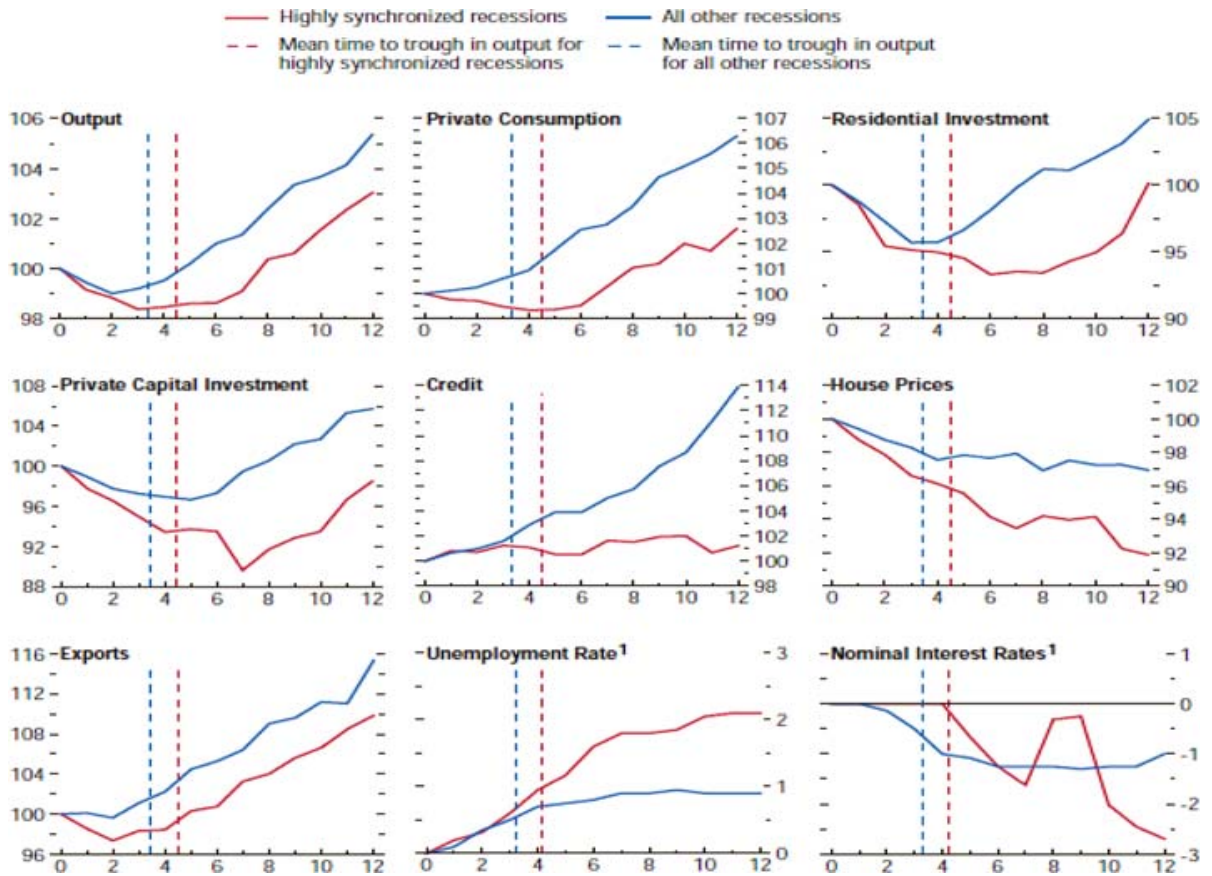

Fig. 4 Highly synchronized recessions are different (median $=100$ at $t=0$; peak in output at $t=0$; data in real terms unless otherwise noted; quarters on the $x$-axis). Source: (IMF 2009a: 114)

\section{Dollars per euro}

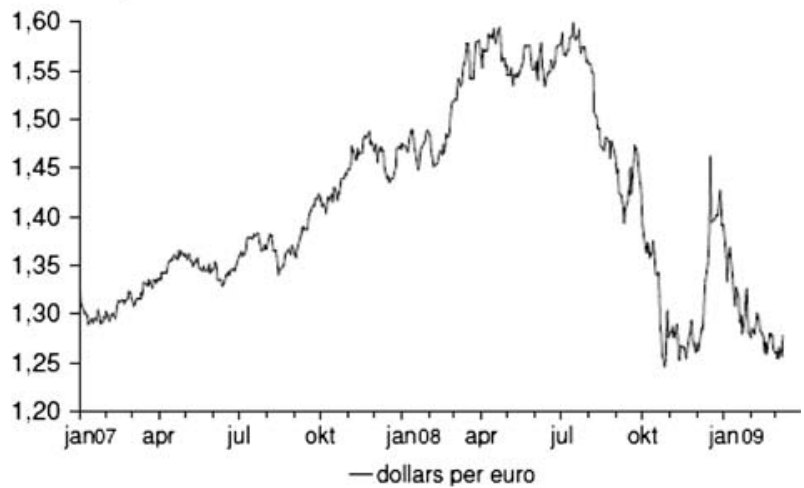

Fig. 5 Volatility in the exchange rate US dollar: euro, January 2007-10 March 2009. Source: CPB (2009: 43)

comes onto the market because owners are unable to keep up the mortgage payments and because the value of the property on a stable market is not immediately clear. There are many dishonest valuators in the US market, who value property on the basis of sale-andprofit strategies and more or less ignore the actual market value. They sell overvalued homes to banks and thus force them into accepting a sizeable capital loss. On an annual 
basis the price of a single-family dwelling fell by $18 \%$ between October 2007 and October 2008.

These problems were exacerbated by the growing popularity of securitisation: the practice of bundling mortgages and trading them on the secondary mortgage market (Aalbers 2008). Rating agencies such as Standard \& Poor, Moody and Fitch drew up the asset-backed securities with a view to getting a triple A rating. So, they were automatically regarded as sound and reliable, but eventually even the experts were unable to properly assess the risks.

The banks and insurance corporations faced serious problems after it transpired that the banks had acquired many bundled mortgages that had been traded on the secondary mortgage market and which had an underlying value that was far lower than the book value (van Hoek 2008).

In the USA Fannie Mae and Freddie Mac were placed under the direct control of the federal administration on September 7, 2008. Eight days later Lehmann Brothers collapsed. Soon afterwards, the US administration and national governments in Europe intervened to bail out the banking system. They bought shares, provided capital injections and guarantees, and became chief shareholders from 1 day to the next.

Pennington-Cross (2002) observes that subprime and FHA market shares are higher in cities with higher economic risk profiles. In contrast, prime lenders concentrate their origination activities in markets with lower economic risks. Recent developments in residential mortgage securitisation in the USA are discussed in greater detail by Haffner (2008).

Though a small country, the Netherlands, relatively speaking, has strong international ties. In 2008 Germany was the greatest exporting country in the world, followed closely by China, the USA and Japan. The Netherlands held a very respectable fifth place, ahead of Italy, France and the UK (World Trade Organisation (WTO) 2009). Because of its international connections the Netherlands is exposed to the fallout from the economic trials and tribulations of other countries. As in China, the Dutch economy in 2009 was particularly hard hit by the steep fall in exports. Unfortunately, this variable does not enter into the analysis of Reinhart and Rogoff (2008a, b, 2009).

In Europe the United Kingdom, in particular, fell foul of the toxic loans that were part and parcel of mortgage securitisation. Italy, Spain and the Netherlands followed, then Germany and France (Schwartz 2008). In the Netherlands various 'system' banks, including ING, ABN AMRO and SNS Reaal, ended up in dire financial straits in 2008. The Dutch government transformed ABN AMRO into a state-owned bank. Meantime the credit crunch was taking a heavy toll on the Dutch insurance sector: The government had to step into rescue Fortis and Aegon. Banks no longer had the resources to grant mortgages or other long-term loans. The Dutch government intervened across the board by partially nationalising the banks and accepting some of the risks. When the banks had sufficiently recovered to lend money again, they tightened the conditions. In the past, it was not uncommon for banks to grant mortgages that amounted to six times the annual income; now they rarely grant mortgages that amount to more than four-and-a-half times the annual income. Banks are also demanding more personal capital and more repayments of the principal. In $200644 \%$ of all mortgages in the Netherlands did not include the obligation for repaying the loan (Ministerie van WWI 2009: 134). Now this share is decreasing quickly. More and more banks do not like offering mortgages without repayments and without personal capital.

In December 2008, the Netherlands Bureau for Economic Policy Analysis (CPB) was predicting a relatively mild recession with a shrinkage of $0.75 \%$ in 2009 . Nout Wellink, 


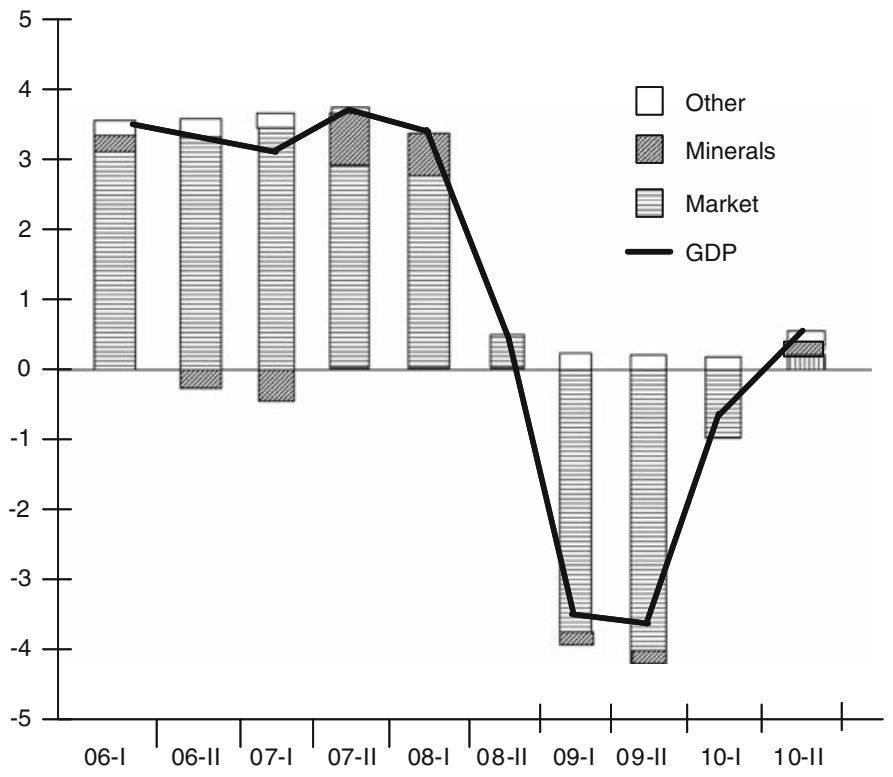

Fig. 6 GDP growth in the Netherlands per half year, compared with the similar period in the year before, 2006 ${ }^{\mathrm{I}}-2010^{\mathrm{II}}$. Source: CPB (2009: 57)

President of the Nederlandsche Bank (DNB), responded almost immediately by describing these forecasts as too optimistic. In the same month, Onno Ruding, former Minister of Finance, predicted shrinkage of 3\% in the first quarter of 2009 and warned for deep repercussions on the National Budget. Wellink placed explicit emphasis on the anticipated rise in unemployment (Giebels 2008).

In June 2009, the Bureau for Economic Policy Analysis (CPB) stated in its Central Economic Plan that, this year, the Netherlands can expect a shrinkage of $3 \frac{1}{2} \%$ in GDP and that, in the course of 2010, unemployment will be around $8.75 \%$ ( $=675,000$ unemployed), nearly the post-war high of $9.6 \%$ recorded in 1983. In August 2009, the CPB adapted these forecasts and predicted a reduction in the output of $4.75 \%$ in 2009 and zero growth in 2010 . Unemployment is supposed to increase to $8 \%$ (=615,000 unemployed) by the end of 2010: still a dramatic perspective. This new forecast provides the basis for the National Budget for 2010.

Figure 6 presents the observed and estimated growth of GDP between 2006 I and 2010 II (CPB 2009: 57).

On 23 December 2008 the following crisis calendar appeared in De Volkskrant newspaper:

22 January 2008: Stock markets worldwide record the worst losses since 11 September 2001

10 February 2008: Worldwide losses due to the collapsing subprime market in the USA are estimated at 400 billion US dollars

7 March 2008: The Federal Reserve pumps 200 billion dollars into the money market, the most dramatic intervention so far

8 April 2008: The IMF reckons that the damage inflicted worldwide by the credit crunch amounts to 1,000 billion US dollars 
continued

26 June 2008: Fortis launches an emergency plan to finance debt

13 July 2008: The collapse of the US mortgage bank IndyMac

30 August 2008: UK Chancellor of the Exchequer Alistair Darling warns for the worst crisis in 60 years

7 September 2008: The US Federal Administration nationalises Fannie Mae and Freddie Mac, which have 5,000 billion dollars' worth of bad mortgages

15 September 2008: Lehman Brothers goes to the wall after the American Administration fails to bail it out

17 September 2008: The credit crunch barely gets a mention in the Queen's Speech in The Hague

20 September 2008: The US wants a state fund. The value is later fixed at 700 billion dollars

23 September 2008: Polls indicate that Dutch savers are concerned about accessing their money

28 September 2008: The Netherlands, Belgium and Luxemburg strike a deal in Brussels in which each buys a part of Fortis

29 September 2008: Black Monday 1 on the stock markets after the Fortis deal and after Congress rejects the Bush Administration's rescue plan (700 billion dollars)

6 October 2008: Black Monday 2: the stock markets in America and Europe are in freefall. The PrimeMinister of Iceland warns that his country is facing bankruptcy

12 October 2008: The EU countries shore up the bank balances with capital injections and mutually guarantee the bank loans

19 October 2008: The Dutch government injects 10 billion euros in ING, later 3 billion euros in Aegon and 750 million euros in SNS Reaa

14 November 2008: All EU euro countries are in recession

25 November 2008: The Federal Reserve prints money and immediately buys up the banks' bad loans

26 November 2008: The European Commission presents a 200-billion-euro recovery plan for the economy

8 December 2008: The Netherlands Bureau for Economic Policy Analysis (CPB) publishes disquieting prognoses for 2009 , predicting that the Dutch economy will shrink by $0.75 \%$

\section{From credit crunch to general recession of the 'real economy' of the Netherlands}

The banking problems in the Netherlands had a snowball effect on the economic sectors that relied heavily on investment goods, durable consumer goods and exports. After some delay, the international haulage industry, the port of Rotterdam, the airport of Schiphol, the steel industry, the car industry and, last but certainly not least, the construction industry and the real-estate market were hit by wave after wave of bankruptcies and job losses.

In March 2009, a delegation consisting of members of the Cabinet and the coalition parties negotiated a package of emergency measures that would be accompanied by a new coalition agreement. The so-called 'Gerritse List' (named after a senior official at the Ministry of Finance) figured strongly in these negotiations. The 'Gerritse List' quantified the effect of alternative spending cuts on the Budget. So, the Cabinet was stimulating the economy and preparing to cut costs at one and the same time (Douwes and Van Keken 2009a, b) (Table 1).

On 25 March 2009 the coalition partners reached agreement on the emergency measures. The supplementary CDA-PvdA-CU (Christian Democrats, Labour and Christian Union parties) coalition agreement entitled 'Working on the Future' offers only a modest boost to the ailing Dutch economy. The Cabinet was already stimulating the economy to a considerable degree via in-built stabilisers that work more or less automatically. It reserved 
Table 1 Effect of cost-cutting measures: the Gerritse list (in percentage of GDP; $1 \%$ is 6 billion euro)

Source: Douwes and Van Keken (2009a)
Link pensions to life expectancy 1.0

Raise tuition fees in higher education 0.1

Economise on the care allowance 0.3

Reduce the duration of unemployment benefit to 1.5 years 0.2

Adapt the imputed rent 0.2

Abolish interest relief on mortgages above 1 million euros 0.5

Raise pensionable age from 65 to 670.7

Abolish transference of tax allowance 0.15

Limit the tax benefits of pension premiums 0.2

Economise on care 0.7

Further pension taxation AOW 0.3

Phase out transference of tax allowance in the referential minimum wage 0.9

an extra 3 billion euros to boost the economy in 2009. This money was earmarked for the labour market, energy saving, building projects and infrastructure. Another 3 billion euros would become available in 2010. According to de Kam (2009a), the incentives for the economy paled into insignificance alongside the future cuts in public spending.

Step by step the Dutch Cabinet decided to come to the aid of the economy by adopting stimulatory measures. Meantime, tax revenue was dwindling, inevitably resulting in a growing deficit in the government account book. These straitened circumstances will undermine the government's capacity to boost and support the economy in the longer term.

The national debt is now growing at the rate of 65 million euros a day. That works out at 24 billion euros a year. The Minister of Finance has to borrow this money. In 2010 the budget deficit will rise to about 35 billion euros. In 2011 another 22 billion euros will be added. If the fundamental budget deficit fails to decline substantially every year, it will reach 92 billion euros by 2018. On August 11, 2008 the Bureau for Economic Policy Analysis adapted its forecasts on the budget deficit in 2009 (from 4.1 to $4.0 \%$ of GDP) and in 2010 (from 6.7 to $6.3 \%$ of GDP). De Kam (2009b) nevertheless foresees a bloodbath when the political parties ask the Bureau for Economic Policy Analysis in 2011 to do the sums for their election programmes. The Netherlands is clearly following the model of Reinhart and Rogoff as far as the budget deficit is concerned.

\section{Sharp fall in housing construction; slight fall in property prices}

In 2008 the number of homes sold in the Netherlands fell by $10 \%$. However, the number of purchases with a National Mortgage Guarantee (henceforth NMG) rose by $14 \%$. A total of 84,103 households used the NMG in 2008: 63,456 to purchase a home and 20,647 to finance home improvements (de Groot 2009). The share of NMG mortgages in the market rose from 55 to $60 \%$. Seventy per cent of new-builds costing less than 265,000 euros (the limit at that time) was backed by a National Mortgage Guarantee. In 2008 the number of compulsory sales with residual debt fell to 927 (compared with 961 in 2007). The expectation for the number of foreclosures in 2009 is about 3,000 now.

Confidence in the housing market took a nose-dive at the end of 2008. The owneroccupier market caved in, especially at the higher end. The serious drop in commissions for architects, developers, construction firms and estate agents would lead to greater 
unemployment and more bankruptcies. The volume on the house-building market fell dramatically because many owner-occupier projects were withdrawn. The exploitation of land showed financial losses, so the construction of more affordable owner-occupier and rental homes often ground to a halt as well. At present consumer spending power is still intact, but consumer confidence struck a low point in the spring of 2009. The decline in output in the construction sector and the relatively low interest rates are aggravating the housing shortage and therefore making for only a very modest fall in property prices. In August 2009 the average fall in the price of homes was $5.6 \%$ on an annual basis (Statistics Netherlands/Dutch Land Registry Office).

Though the housing associations are also being hit by the credit crunch, they are being asked on all sides to continue with rental dwelling projects and to take over projects from commercial developers and realise them, usually in the form of temporary or permanent rental housing. Two public banks-the Bank Nederlandse Gemeenten (Municipalities Bank) and the Waterschapsbank (Water Boards Bank)—saw their stake in the housing association market rise from around $60 \%$ to over $90 \%$ in 2008 and 2009 .

Nevertheless, also housing associations have been severely hurt by the credit crunch and by current policies of the national government. The rigid rent policy, the introduction of a corporation tax for all housing associations, and the lower number of housing units sold by housing associations have together considerably reduced the capacity of housing associations to invest in new construction.

The credit crunch and the subsequent deterioration in the real economy are having strong effects on the market for housing and housing construction (see van Hoek 2008):

- Residential mobility has been slowing down by more than 10\% in 2008/2009: more people are staying put;

- There are fewer divorces and fewer new households being formed: the dilution of the family is undergoing a temporary interruption and the demand for housing is growing at a slower rate than before;

- Banks and mortgage providers have adopted more cautious lending policies, which have been partly responsible for the steep decline in projects by private developers and construction firms. People who want to take out a mortgage are experiencing more constraints and barriers than before;

- Housing market demand is shifting from owner-occupation to renting, and from expensive to cheap (see Fig. 7).

Hans Hoogervorst, Chairman of the Netherlands Authority for the Financial Markets (AFM), has stated that in one out of every four cases, the mortgage advice given in the Netherlands is inadequate. He has also expressed concern about overcrediting on the housing market: unlimited deductibility of mortgage interest has led to too many top mortgages. Almost 50\% of all mortgages are interest-only mortgages. People with an interest-only top mortgage do not build up any capital under the current circumstances and may be exposed to huge negative-equity risks if property prices fall (Giebels and van Uffelen 2009).

After the disappointing fourth quarter of $2008(-2.5 \%)$ the housing market deteriorated further in the first quarter of 2009, when the selling price of an average home fell by $3.1 \%$ to 218,000 euros. According to the Dutch Association of Real Estate Brokers (NVM), the number of sold dwellings fell to 19,200-down $40 \%$ from the first quarter of 2008. The number of sold dwellings (NVM \& non-NVM members) in the first quarter of 2007 was still around 25,000 (NVM press release, 9 April 2009). 


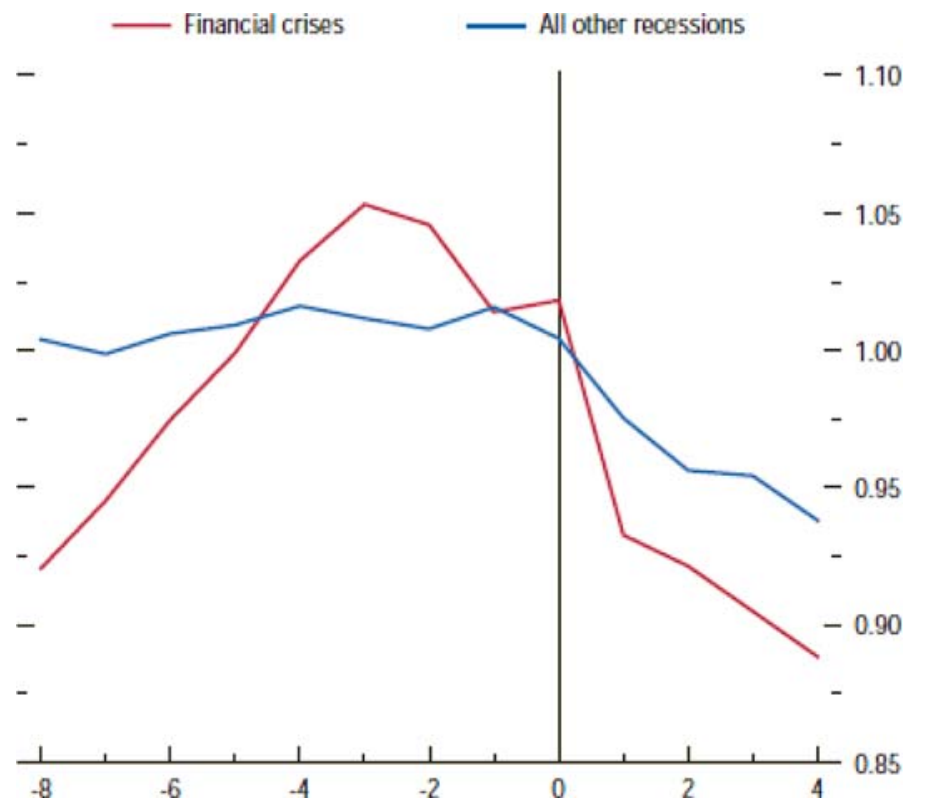

Fig. 7 House Price-to-Rental Ratios for Recessions Associated with Financial Crises and Other Shocks (Peak in output at $t=0$; quarters on the $x$-axis). Source: IMF (2009a: 110)

After the first quarter of 2009 the NVM announced that the Dutch housing market had reached a new low. The average property price had fallen by $3.1 \%$, sales had almost halved, selling time had risen from 84 to 105 days, and it was almost impossible to sell homes at the top end of the market. In the third quarter of 2009 the average selling price stabilised $(+0.1 \%)$ and so did the number of transactions. The average selling time stabilised as well, on a level of 108 days.

The Home Ownership Guarantee Fund (Waarborgfonds Eigen Woningen) was processing 650 new cases in the first quarter of 2006 compared with around 500 in the first quarter of 2008 .

Brounen (EUR) anticipates a 10\% fall in prices for the Netherlands in 2009, but stresses the uncertainties (van den Eerenbeemt 2009). In one group of countries the decline in the housing market is causing an economic recession (US, UK, Ireland). In another group it is the economic recession that is causing a decline on the housing market. The Netherlands belongs to the second group (alongside Canada and Norway amongst others).

Figure 8 presents the changes in average house price per quarter since 1998, not corrected for differences in quality.

Figure 8 shows that, since the end of 2008, house prices in the Netherlands have been going down gradually. The decline is smaller than in many other European countries (Fig. 9). This can be explained in part by the general housing shortage in the Netherlands, sustained by the fall in housing construction, and in part by the large size of the rented sector which can absorb some of the housing demand. We observe a shift in this demand from owner-occupation to renting. In addition there are institutions in the Netherlands which may contribute to the stabilisation of the housing market: the National Mortgage Guarantee (NMG); the housing associations (which sell properties at a moderate price and reduced risk for households); the Authority Financial Markets (AFM), which supervises 


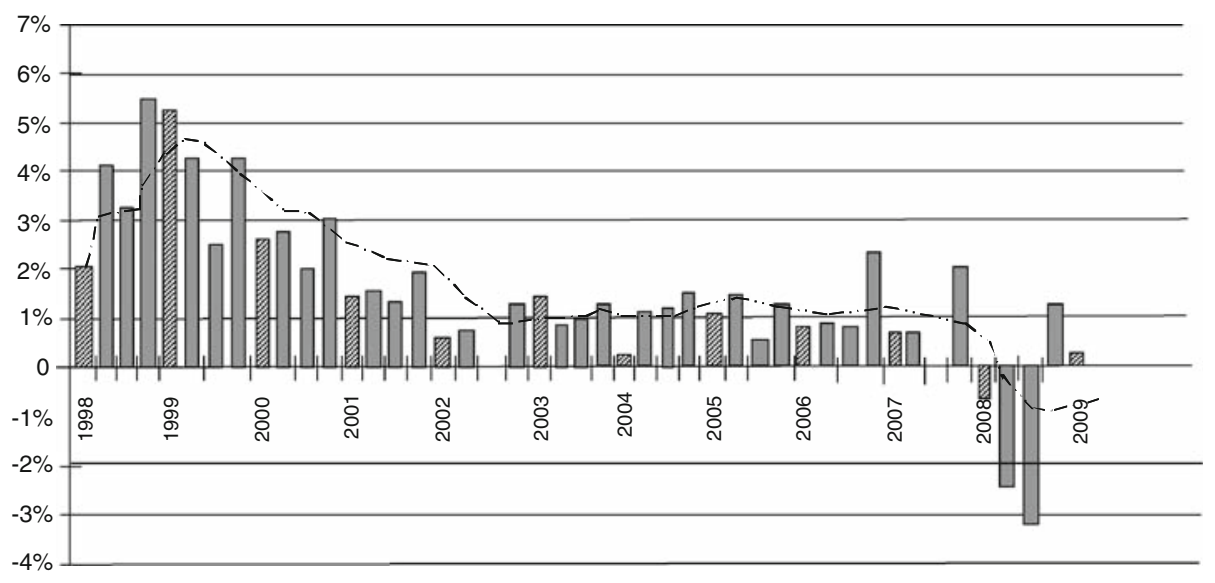

Fig. 8 Changes in the house prices per quarter, 1998-2009. Each column represents the change (in \%) in price of housing units sold, compared with the previous quarter. The dotted line represents the average of last four quarters
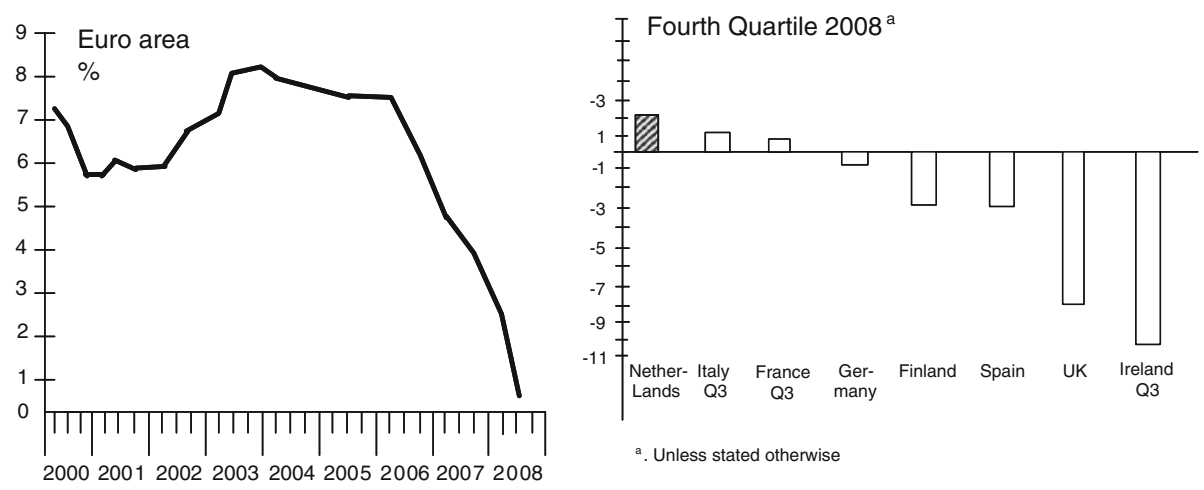

Fig. 9 House prices in Europe, 2000-2008. Source: CPB (2009: 30)

mortgage markets; the absence of subprime mortgage markets; the deductibility of mortgage interest for income tax; and the position of some banks, like the RABO bank, which appear to be resilient in difficult times.

Figure 9 presents the development of house prices in Europe, 2000-2008. The differences between countries are very large, the Netherlands being a positive (or slow?) case.

In April 2009 the Netherlands Authority for the Financial Markets (AFM) failed to persuade Dutch parliament to impose a ban on top mortgages. On 23 April, Deputy Minister de Jager promised the House of Representatives that there would be no such ban, but he stressed at the same time that overcrediting needed to be contained as much as possible. Banks have become wary of overcrediting; they want households to invest more capital and to repay the principal. Top mortgages are not officially banned, but they are far less popular than a few years ago. 
In early 2009 the majority of the housing associations reported that their liquidity position was coming under pressure (Aedesnet Nieuws, 21 January 2009) as a result of the rigid rent policy, corporation tax, the Vogelaar levy (a tax imposed on housing associations to guarantee funding for the regeneration of 40 rundown urban neighbourhoods) and the credit crunch. Almost half of the housing association projects are at a standstill because of the deterioration in the financial position.

The housing association sector was knocked sideways in mid-2009 when news broke that over one hundred housing associations had been accorded B status by the Central Housing Fund (Centraal Fonds Volkshuisvesting)—which placed them in the financial danger zone. There are still more than 300 housing association which are financially healthy and are able to construct social rented dwellings. Public banks, such as the Bank Nederlandse Gemeenten and the Waterschapsbank (both with Triple A status), are still willing to grant loans to housing associations at what are essentially reasonable rates. Although the housing association sector does not adopt fixed ROI targets, they are mostly not able to 'save' commercial housing projects.

Housing associations can certainly not rescue many bogged-down development projects. Housing associations must eschew irresponsible risks. According to Van Heuven (Director of Aedes), "Housing associations will only consider taking over commercial building projects, as the Cabinet suggests, if this fits into their business operations and the local building remit" (Harms 2009: 13).

Two years ago, Aedes (the umbrella organisation of Dutch housing associations) solemnly promised that the housing associations would produce 40,000 new homes every year. That was before the credit crunch. Although housing associations are the traditional champions of anticyclical building, the expectation is that they will not achieve this level of production in the years ahead. A reduced total annual housing production of 60,000 is expected to be realised in both 2009 and 2010, with a higher share of housing association units.

\section{Three letters from the Housing Minister}

The Cabinet's policy to boost the construction and housing markets in these troubled economic times was set out in three letters from the Dutch Housing Minister, Eberhard van der Laan.

\subsection{Letter from the Housing Minister, 30 January 2009}

The first letter (van der Laan 2009a), published on 30 January 2009, draws attention primarily to the individual responsibility of the players on the housing market. At this juncture the Cabinet announced two measures:

- A temporary increase in the guarantee limit of the Guarantee Fund for Housing Associations (Waarborgfonds Sociale Woningbouw, WSW) (was: 200,000 euros);

- Improvements to the housing cost scheme in the National Mortgage Guarantee to help households with payment difficulties.

The increase in the guarantee limit of the Guarantee Fund enabled the housing associations to take over immobilised commercial housing projects. This new option is not being used by the housing associations so far. The main purpose of the improvements to the housing cost scheme is to prevent compulsory sales by making special payment arrangements or even suspending payments when necessary. 
6.2 Raising the limit of the National Mortgage Guarantees

Since the end of 2008 interest groups (Neprom, Bouwend Nederland, NVB, NVM) have been urging the government to raise the limit of the National Mortgage Guarantee from 265,000 euros to 350,000 euros. On 4 December 2008, Brigitte van der Burg, Member of Parliament for the VVD (People's Party for Freedom and Democracy) tabled a motion to temporarily raise the limit from $€ 265,000$ to $€ 350,000$ (2008-2009, 31700 XV III, nr. 22). The motion was discussed in the House of Representatives on 19 December 2008, but the Cabinet decided not to follow the proposal of the House. A half year later the Cabinet was to change its opinion.

\subsection{Purchase fund for unsellable homes}

In April 2009 the Dutch press reported that development companies were planning to set up a purchase fund in association with municipalities, provinces and the building sector. The purchase fund offers to buy homes from people who want to move into a new-build but are unable to sell their current home. What happens is that a buyer signs a deal for a new-build. The contract contains a clause which states that if he is unable to sell his current house within a fixed period, the guarantee fund will buy it for $90 \%$ of the valuation price. Under these terms the buyer is then obliged to accept any other offer of $90 \%$ of the valuation or higher. The purchase fund serves explicitly as a sort of safety net (Garschagen and van der Steen 2009). To the best of our knowledge, very few people have made use of this scheme. Most households are unable to absorb a reduction of $10 \%$, which usually amounts to between 25,000 and 35,000 euros. The market players had hoped that the national government would join the scheme but the Cabinet was so clever to decline.

\subsection{Letter from the Housing Minister, 15 May 2009}

On 15 May 2009 Minister Van der Laan sent a second letter (van der Laan 2009b) to the House of Representatives on 'emergency measures for the house-building market'. Earlier, on 25 March 2009, the supplementary coalition agreement 'Working on the Future' had been formally signed.

The package offered by the Cabinet amounts to over 700 million euros for 2009 and 2010:

a. An incentive budget of $€ 395$ million to boost the construction of market-sector housing units (specified in detail in the letter of 12 June 2009).

b. $€ 320$ million in energy investment allowances to stimulate sustainable investment by owner-occupiers and tenants.

Re: (a) New-builds are expected to drop to 60,000 in 2011, far short of the required 83,000 . The housing shortage will increase by $1.8 \%$ in 2012 . The Economic Institute for the Building Industry predicts that 50,000 jobs will come under threat in the construction sector in 2009 and 2010. The demand for housing will grow by another 500,000 households by 2020, with substantial regional differences. A condition for obtaining a subsidy from national government is that other players (municipality, housing associations, commercial actors) show a willingness to make extra investments. Most municipalities can contribute via their land policy. 
Re: (b) Stimulating sustainable investment The most important instrument is the extension of the energy investment allowance (EIA) for energy-saving investments in business machinery for 2009-2010, with energy-saving investments in existing rented dwellings ( $€ 160$ million in $2009+€ 160$ million in 2010$)$ subject to energy label B or a two-step improvement. A maximum investment of $€ 15,000$ per dwelling applies for the energy investment allowance (44\% deduction before fiscal profit determination). These arrangements seem particularly attractive for housing associations: 100,000 extra dwellings a year with energy-saving measures for 2009-2010 compared with the current Energy-Saving Covenant in the housing association sector.

The package of measures for owner-occupiers who are facing double-costs calls for the following:

- Improve the housing costs scheme;

- Stimulate and make better use of the possibilities offered by the Vacancy Act (Leegstandswet) to rent out unsold properties temporarily;

- Make a broader analysis of these households together with the Ministry of Social Affairs.

The purpose of the housing costs scheme in the National Mortgage Guarantee (NMG) is to temporarily match the mortgage burden with the current, lower income of people with payment problems. This scheme was introduced before the summer of 2009. Possibilities for temporary rental under the Vacancy Act must be enhanced. The possibility of raising the NMG limit will be further explored.

\subsection{Letter from the Housing Minister, 12 June 2009}

The third letter of van der Laan (2009c) was published on 12 June 2009. The sum of $€ 395$ million (an extra $€ 245$ million) will be freed up for the temporary incentive schemes for new-building projects in 2009, based on Sect. 20 of the Urban Renewal Act (Wet Stedelijke Vernieuwing), and for specific investment in the restoration of monuments for 2009 and 2010. The aim of the incentive scheme is to kick-start stagnating or postponed projects: "The scheme will enable municipalities, project developers, housing associations and builders to continue to build as much as possible at their own-market-risk."

There is a much stronger decline in the construction of owner-occupier dwellings than rental dwellings. The Ministry for Housing, Communities and Integration does not anticipate a slump in the construction of social rental dwellings in the next few years.

Since 1 July 2009, the Social Housing Guarantee Fund has guaranteed loans that fall under the rent regulation limit of $€ 647.53$ per month.

The subsidy programme is split into three rounds: one in June 2009; one in the second half of 2009; and one in the spring of 2010. Projects will be submitted via the municipalities.

There is a maximum one-off grant of $€ 10,000$ per dwelling per project.

The first part of the application for the building permit had to be submitted to the municipality before 25 March 2009 and construction will have to start in the same year.

The first round allocated a maximum of $€ 100$ million in subsidies and operated via a tendering system. After the deadline, the applications from the municipalities were prioritised and grants were awarded until the budget for the first round was exhausted. The first round has been oversubscribed by a factor of more than two, so half of all applications 
failed to get through. In August $2009 € 100$ million euros were allocated for a total of 15,000 housing units.

If construction does not start before January 1, 2010 the subsidies must be paid back. It is not clear yet whether the subsidy scheme is efficient (transaction costs not too high) and effective (really stimulating supply).

Projects for the restoration of municipal monuments will also be subsidised (change of function for non-residential buildings). A total of $€ 13$ million in grants will be awarded for six named monuments and will lead to a total investment of around $€ 38.2$ million in building projects.

The Cabinet is deciding in steps to bring forward projects in the civil engineering and the real estate construction sector to reduce the threat of unemployment. On 19 June 2009 the Cabinet decided to make $€ 320$ million available for the construction and renovation of care institutions.

\subsection{Raising the NMG limit for costs}

On 19 June 2009 the Cabinet decided, after initial resistance from the Ministry of Finance, to temporarily raise the NMG limit from 265,000 euros to 350,000 euros for new owneroccupier homes. The new limit came into force on 1 July 2009 and will continue till 2011. The House of Representatives had already adopted the motion by Van der Burg (VVD) to this effect in December 2008. The Cabinet had discovered that this wider scope of NMG did not increase the financial risks for the State. The Cabinet reserved 9 million euros to absorb any blows that might result from this move. The impact is that the number of NMG applicants is increasing to a substantial extent.

It might be advisable for the NMG to capitalise on its stronger market position by setting further conditions on the types of mortgage that fall under the mortgage guarantee. That way, it could help reduce the risks to households and banks. This would harmonise with the in-built 'deleverage' aims of the banks, i.e., to promote simple products, reducing leverages and containing the risks for the customers and themselves.

\section{Is the Dutch economy following the pattern sketched by Reinhart and Rogoff?}

This article has discussed how the credit crunch started in the USA and spread to the Netherlands and other European countries. Figure 10 shows a causal diagram of the credit crunch and the current problems facing the Dutch housing market.

Boxes 1 and 2 show the immediate manifestations of the credit crunch in the USA, without elaborating on the subsequent problems in the US real economy. In Box 3 secondary mortgages - including many toxic mortgages - are exported from the USA to Europe, including the Netherlands. National governments support system banks and reduce the risks; the banks start to deleverage and introduce restrictions on capital markets (Box 4). The credit crunch has a devastating impact on stock exchanges in many parts of the world, including the Amsterdam Stock Exchange, and the AEX index plummets (Box 5). The real economy in the European Union takes a beating which has a devastating impact on the open economy of the Netherlands (Box 6): exports fall; housing sales decline; investment industries, including the construction industry, are hit. After a while, bankruptcies multiply and unemployment rises after a dip in consumer confidence. The public is increasingly opting to save their money and there is a fall in investment (Box 7). 
Banks have problems as a result of lack of interbank confidence and bad experiences with toxic financial products on the secondary mortgage markets; credit crunch.

Secondary mortgages are exported from USA to Europe, in particular the UK, the Netherlands, Spain and Italy. National governments support system banks.

Banks introduce restrictions on mortgage markets and long-term capital markets

Sudden credit restrictions cause share prices to plummet on the stock markets.

6

Real economy in European countries is hit: exports fall, house sales fall, construction industry is hit, car sale fall, steel industry is hit, etc.

Declining consumer confidence, investments fall, savings increase, multiple bankruptcies, rising unemployment.

Mobility slows down. Households are aware of increasing probability of job losses. Growing uncertainty. Sharp fall in transactions on the owneroccupier market. Housing construction caves in. Architects, developers, construction firms and subcontractors report lower turnovers.

Unemployment rises in the construction sector.

9 housing. Demand shifts from expensive to cheap and from ownership to rental. Gradual fall in house prices. Housing associations sell fewer dwellings. Housing association finance becomes more restricted.

As projects for upmarket homes come to a halt, the budgets for land exploitation are no longer square. This causes stagnation in parts of the output in (social) rental dwellings.
10 Governments receive less tax revenue and spend more on incentives.

11 Governments forced to economise. This places tighter limits on the incentive policy.

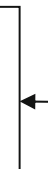

12

Government helps Dutch housing market only to a limited extent.

13 New WSW levels (Guarantee Fund Social Housing). New NMG levels (National Mortgage Guarantee).

Subsidies for new-builds and stock policy. Retention of new corporation tax for housing associations.

Problems on the Dutch housing and house-building market: many owner-occupier projects put on hold. Output of owner-occupier dwellings falls sharply. Housing associations are invited to take over some of the stagnating projects. This is facilitated by raising the WSW limit. But housing associations maintain the construction of social rented dwellings and are mostly not able to 'save' commercial projects. Housing associations are also hampered by financing problems, a rigid rent policy, the corporation tax for housing associations and a decline in the sale of dwellings in the existing stock.

Fig. 10 Causal diagram of credit crunch and current problems on the Dutch housing market 
In Box 8 transactions in the owner-occupier market diminish and the output of new housing takes a downturn. Architects, developers, contractors and real estate agents have fewer commissions. There is a steep rise in unemployment in and around the construction sector.

Box 9 shows a shift in the demand for housing from 'expensive' to 'cheap' and from 'owner-occupation' to 'renting'. House prices are gradually slipping. Housing associations sell fewer properties, which compromises their financial capacity to invest in new projects.

The national government is confronted with lower tax revenue and higher expenditure (Box 10). Looking ahead, the government must introduce budget cuts and thereby its capacity to provide incentives is weakened (Box 11). Box 12 shows that the Dutch government is stimulating the housing market only to a limited extent.

The limits of the Social Housing Guarantee Fund (WSW) and the NMG are lifted (Box 13). Temporary limited subsidies are introduced for new market projects and for renovation of the existing housing stock. However, the corporation tax for housing associations is maintained.

Box 14 shows that new housing projects are so intertwined with land cost allocations that stagnation in expensive owner-occupier dwellings is automatically accompanied by stagnation in new (social) rented dwellings.

In Box 15 it emerges that problems on the Dutch housing market are multi-faceted: many owner-occupier projects have been put on hold. Attempts by housing associations to take over some of these projects are facilitated by the new limit of the Social Housing Guarantee Fund. But they are being hampered in their efforts by stringent financing conditions, a rigid rent policy and falling sales of social housing.

At the time of writing (October 2009), average house prices are falling by $5.6 \%$ on an annual basis (corrected for differences in quality). Output on the house-building market has fallen from around 80,000 units (80,500 in 2007 and 79,000 in 2008) to around 60,000 in 2009. Forecasts vary for 2010. In April 2009, the Bureau for Economic Policy Analysis (CPB 2009: 74) expected for 2009 78,000 new dwellings to be completed, and for 2010 69,000 new dwellings. Taco van Hoek (Economic Institute for the Building Industry) predicts that output will stand at around 60,000 units in both 2009 and 2010. The Director of the NVB association of building contractors and developers, Nico Rietdijk, believes that, in 2010, housing production will stop short at 30,000 units (Laverman 2009). This gloomy forecast might be explained by the fact that Rietdijk represents the interests of a market player with a strong focus on the construction of (mostly expensive) owneroccupier dwellings and therefore fails to notice that the demand for rented housing is as great as ever and that the housing associations in general could mobilise substantial resources from the above-mentioned public banks.

The construction industry had an excellent year in 2008, with high output levels in civil engineering and building construction. The tightness in the labour market at that time was eased to some extent by a substantial influx of Polish construction workers. At the end of 2008 the order books of Dutch construction firms were bulging, but the flow soon started drying up at an unprecedented rate. In December 2008 Van Hoek predicted that 30,000 people in the construction industry would be out of a job at the end of 2009 and 2010. After the Netherlands Bureau for Economic Policy Analysis had revised its economic prognosis for 2009 from a shrinkage of $0.75 \%$ to a much gloomier $3.50 \%$ in GDP, Van Hoek changed his unemployment prognosis from 30,000 to 50,000 .

Between the end of 2007 (515 points) and the end of 2008 ( 246 points), the AEX went down by more than 50\% (CPB 2009: 66).

Remarkably, in mid-July 2009, the stock markets in the Netherlands (along with other European countries and the USA) picked up and improved for nine consecutive days (see Fig. 11). 


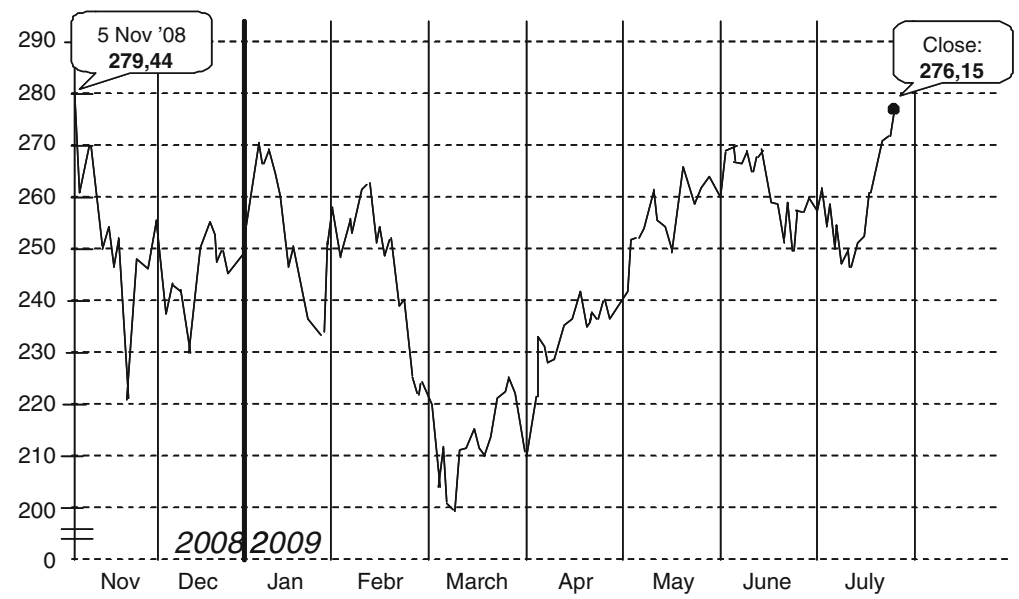

Fig. 11 AEX index November 2008-July 2009

The general impression is that the economic situation in the Netherlands has reached its lowest ebb. No one can tell whether it is gearing up for a rapid recovery or whether more blows can be expected in the near future. Four black clouds are hanging over the Dutch economy: a rapid rise in unemployment to $8 \%$ at the end of 2010; the extreme high level of mortgage debt (the highest in the European Union, together with Denmark); the obligation for pension funds to increase the coverage for their financial commitments; and the widening deficit in the national budget, which is compelling the government to cut public expenditure. Whether the Dutch economy and the Dutch construction and housing market will follow the general pattern of Reinhart and Rogoff, through 5-6 years of crisis, or whether it will recover much sooner is the million-dollar question which Dutch housing market experts are at a loss to answer at the moment.

The answer to this question is probably closely related to the answer to the question of how long the current global economic crisis will last. Some economists believe it will be a short, intense period of contraction followed by rapid recovery and growth: a so-called V-shaped recession (IMF 2009b; Kalse 2009). But among economists there is increasing support for the model of a $\mathrm{W}$-shaped recession: a deep contraction, followed by a short period of recovery as a prelude to another major contraction before the final recovery sets in. If the global recession ends up being $\mathrm{W}$-shaped, it will follow the general pattern identified by Reinhart and Rogoff and IMF (2009a: 112). In that case the chance that the Dutch credit crunch, including a fall in house prices during at least 4 years, will also follow the pattern set by Reinhart and Rogoff, is large as life.

Open Access This article is distributed under the terms of the Creative Commons Attribution Noncommercial License which permits any noncommercial use, distribution, and reproduction in any medium, provided the original author(s) and source are credited.

\section{References}

Aalbers, M. B. (2008). The financialization of home and the mortgage market crisis. Competition \& Change, 12(2), 148-166. 
Buckley, R., Karaguishiyeva, G., van Order, R., \& Vecvagare, L. (2003). Comparing mortgage credit risk policies: An options based approach, worldbank policy research working paper 3047, Washington DC (Worldbank).

Centraal Planbureau (CPB). (2009). Centraal Economisch Plan 2009 [Central Economic Plan 2009]. The Hague: CPB.

de Groot, A. (2008). 'Euro is in crisistijd baken van rust' [Euro is a beacon of tranquillity in critical times], de Volkskrant, 31 December.

de Groot, A. (2009). 'Aantal hypotheken met garantie neemt fors toe' [Steep rise in the number mortgages with a guarantee], de Volkskrant, 24 January.

de Kam, F. (2009a). Coalitie baart begrotingsmuis met grote staart [Coalition budget like a mouse with a long tail], NRC Handelsblad, $4+5$ April.

de Kam, F. (2009b). Overheid zakt weg in moeras van schulden [Government sinking in a swamp of debt], NRC Handelsblad, $11+12$ July.

Di Martino, D., \& Duca, J. V. (2007). The rise and fall of subprime mortgages. In: Federal Reserve Bank of Dallas, Economic Letter, 2, no. 11, November www.dallasfed.org.

Douwes, D., \& van Keken, K. (2009a). Burger gaat crisismaatregelen voelen [Man in the street will feel emergency measures], de Volkskrant, 1 March.

Douwes, D., \& van Keken, K. (2009b). Politiek dynamiet in lijstje-Gerritse [Political dynamite in the Gerritse List], de Volkskrant, 2 March.

Garschagen, M., \& van der Steen, P. (2009). Opkoopfonds moet woningmarkt aanjagen [Purchase fund to stimulate housing market], NRC Handelsblad, 2 April.

Giebels, R., (2008). Volgens Wellink wordt het nog erger [Wellink says things will get worse], de Volkskrant, 23 December.

Giebels, R., \& van Uffelen, X. (2009). 'Faillissement Lehman was moedig besluit' [Lehman bankruptcy was a brave decision], de Volkskrant, 23 December.

Haffner, M. E. A. (2008). Subsidization as motor to residential mortgage securitization in the US. Journal of Housing and the Built Environment HBE, 23(4), 337-351.

Harms, E. (2009). Hoe staat de woningmarkt ervoor? [What is the state of the housing market?]. Tijdschrift voor de Volkshuisvesting, 15(3), 11-15.

Immergluck, D. (2009). Foreclosed. High-risk lending, deregulation, and the undermining of America's mortgage market. Ithaca and London: Cornell University Press.

International Monetary Fund (IMF). (2009a). World Economic Outlook. Crisis and recovery. Washington DC: IMF.

International Monetary Fund (IMF). (2009b). World economic outlook. Update. Washington DC: IMF.

Janssen, R. (2009). 'Financiële crises hakken erin' [Financial crises take their toll], NRC Handelsblad, 14 January.

Kalse, E. (2009). V-vormig of W, dat is de vraag. Onzekerheid over economische crisis na nieuwe Amerikaanse cijfers [V-form or $\mathrm{W}$, that is the question. Uncertainty about economic crisis remains after American figures], NRC Handelsblad, August $1+2$.

Laverman, V. (2009). 'Slechts 30.000 nieuwbouwwoningen in 2010' [Only 30,000 new dwellings to be built in 2010], Building Business, June/July: 54-55.

Ministerie van Wonen, Wijken en Integratie (WWI) (2009). Cijfers over Wonen, Wijken en Integratie [Data about Housing, Communities en Integration], The Hague (Ministerie van VROM-WWI).

Pennington-Cross, A. (2002). Subprime Lending in the Primary and Secondary Markets. Journal of Housing Research, 13(1), 31-50.

Reinhart, C. M., \& Rogoff, K. S. (2008a). This time is different: a panoramic view of eight centuries of financial crisis, National Bureau of Economic Research Working Paper 12882, Cambridge (Mass.) (NBER), March.

Reinhart, C. M., \& Rogoff, K. S. (2008b). Banking crises: An equal opportunity menace, National Bureau of Economic Research Working Paper 14587, Cambridge (Mass.) (NBER).

Reinhart, C. M., \& Rogoff, K. S. (2009). The aftermath of financial crises, Paper presented at American Economic Associations meeting in San Francisco, College Park (Maryland) and Cambridge (Mass.), January 3.

Sanders, A. (2008). The subprime crisis and its role in the financial crisis. The Journal of Housing Economics, 17, 254-261.

Schwartz, A. F. (2008). Presentation at roundtable 'The Mortgage Mess: Origins, Impacts and Prospects for Recovery', ACSP-AESOP Conference Chicago, Track 5. Housing and Community Development, Chicago, July 8.

Shiller, R. (2008). The subprime solution: How today's global financial crisis happened, and what to do about it. Princeton: Princeton University Press. 
van den Eerenbeemt, M. (2009). 'Huizenmarkt staat overal op instorten' [Housing market everywhere on the verge of collapse], de Volkskrant, 2 January.

van der Laan, E. E. (2009a). Analyse woningmarkt en overheidsinstrumentarium, [Analysis of the housing market and government instruments] Brief aan de Tweede Kamer der Staten-Generaal, The Hague (Ministerie van VROM-WWI), 30 January.

van der Laan, E. E. (2009b). Crisismaatregelen woningbouwmarkt [Emergency measures for the house building market], Brief aan de Tweede Kamer der Staten-Generaal, The Hague (Ministerie van VROM-WWI), 15 May.

van der Laan, E. E. (2009c). Stimuleringsbudget woningbouw [Incentive budget for the house-building sector], Brief aan de Tweede Kamer der Staten-Generaal, The Hague (Ministerie van VROM-WWI), 12 June.

van Ewijk, C., \& Teulings, C. (2009). De grote recessie. Het Centraal Planbureau over de kredietcrisis [The big recession. The Netherlands Bureau for Economic Policy Analysis writes about the credit crunch], Amsterdam (Balans).

van Hoek, T. (2008). De Vastgoedlezing 2008. Crisis op de Nederlandse woning- en vastgoedmarket?[The Real Estate lecture 2008. Crisis on the Dutch housing and real-estate market?], Amsterdam (Amsterdam School of Real Estate).

World Trade Organisation (WTO) (2009). World Trade Report 2009, (WTO).

Wyly, E. K., Atia, M., Foxcroft, H., Hammel, D. J., \& Phillips-Watts, K. (2006). American home: Predatory mortgage capital and neighbourhood spaces of race and class exploitation in the United States. Geografiska Annaler, 88 B, 105-132. 